\title{
The Emotional Intelligence of Senior Executives and their Effect on Products Innovation and on Processes Innovation
}

\author{
Carmen Dolores Blázquez-Puerta \\ blazquezCD@alu.uma.es \\ PhD Student. PhD Program in Economics and Business \\ University of Málaga. Spain \\ Guillermo Bermúdez-González \\ gjbermudez@uma.es \\ Professor - Department of Economics and Business Administration \\ University of Málaga. Spain
}

\begin{abstract}
The main aim of this empirical research is to prove that the emotional intelligence of senior executives exerts a direct and positive effect upon innovation across different enterprises. The study uses total sample of 139 senior executives belonging to Spanish companies engaged in a wide range of activities who were required to complete a 22item survey. In addition to validating the conceptual model, the outcome of the empirical analysis based on application of the structural equation model confirm the -"starting hypothesis"-: -"the emotional intelligence of senior executives exerts a direct and positive effect upon product innovation and process innovation within enterprises"-.
\end{abstract}

Keywords: Emotional intelligence, Product innovation, Process innovation 


\section{Introduction}

Innovation is regarded as a significant dimension within the process of learning at work, which implies rational, intuitive, emotional and social processes; while emotion plays a very important role in influencing employees and in their willingness to create and innovate (Fenwick, 2003). According to Helfat and Martin (2012), creativeness and innovation within different organizations depend on the capacity of members of management to measure the different possibilities.

Emotions can exert a certain degree of influence upon human thought processes and opinions through the promotion of different information strategies (Forgas, 1995). According to Mayer and Salovey (2007), there are four basic talents inherent to emotional intelligence: 1) "understanding, evaluating and expressing emotions"; 2) "the effect on ideas"; 3) "understanding of the changeable and complex structure of emotions" that affect decision- makings, and 4) "supporting emotional and intellectual expansion" (Charbonneau and Nicol, 2002).

Positive emotions could facilitate the heuristic process as being useful for "creative jobs" (Lyons and Schneider, 2005).

Park (2005) supports the idea that the quality of the emotional environment within different organizations can improve creativeness and productivity.

Employees with a greater emotional intelligence (EI) have a greater command of their capacity for negotiation and problems-solving (Goleman, 1998), which is the basis for "creative ideas" (Scott and Bruce, 1994). The process of creating ideas is the first step in the process of individual innovation.

\section{Theoretical framework and conceptual model proposed}

Considering a systemic focus in which; the starting point is the individual joining the organization (Tejada, 2003) our theoretical framework is based upon the dual model of intelligence proposed by Norman and Shallice (1986), and the winner of the 2002 Nobel Prize for Economics, Daniel Kahneman (2012), who explains: "The mind has two systems: System 1 (Fast brain), fast, intuitive and emotional, operates quickly and automatically, with little or no effort and no sense of voluntary control" and System 2 (slow brain), slower, hard and rational, focuses attention on the hard-working mental activities that demand it, Its operations are often associated with the subjective experience of acting, choosing and concentrating."

In the present study, we will concentrate only on System 1 ( upon the Affective System at the stage of humanbeing and upon the Emotional Intelligence (EI) at an Organizational level; and inside the System 2 at individual level is identified with the taking of decision related to the innovation (Innov) at the enterprise (see figure 1).

This conceptual model is based upon the theoretical framework shown above and is based on the following principle: for managers to have the capacity to exert some influence upon the outcome of products as much as process innovation within the enterprises they are running, they should develop emotional intelligence, which promotes awareness both of aid having both of oneself and of others: by making use of their emotions according to the different situations they face, as well as their capacity to 
regulate emotions (Mayer and Salovey, 2007; Wong and Law, 2002; Jordan and Troth, 2002; Suliman and Al-Shaikh, 2007; Shih and Susanto, 2010).

Finally, the aim is to prove empirically that the emotional intelligence of seniors executives exerts a direct and positive effect upon innovation within enterprises, especially in terms of product and process innovation.

Figure 1. Conceptual model proposed

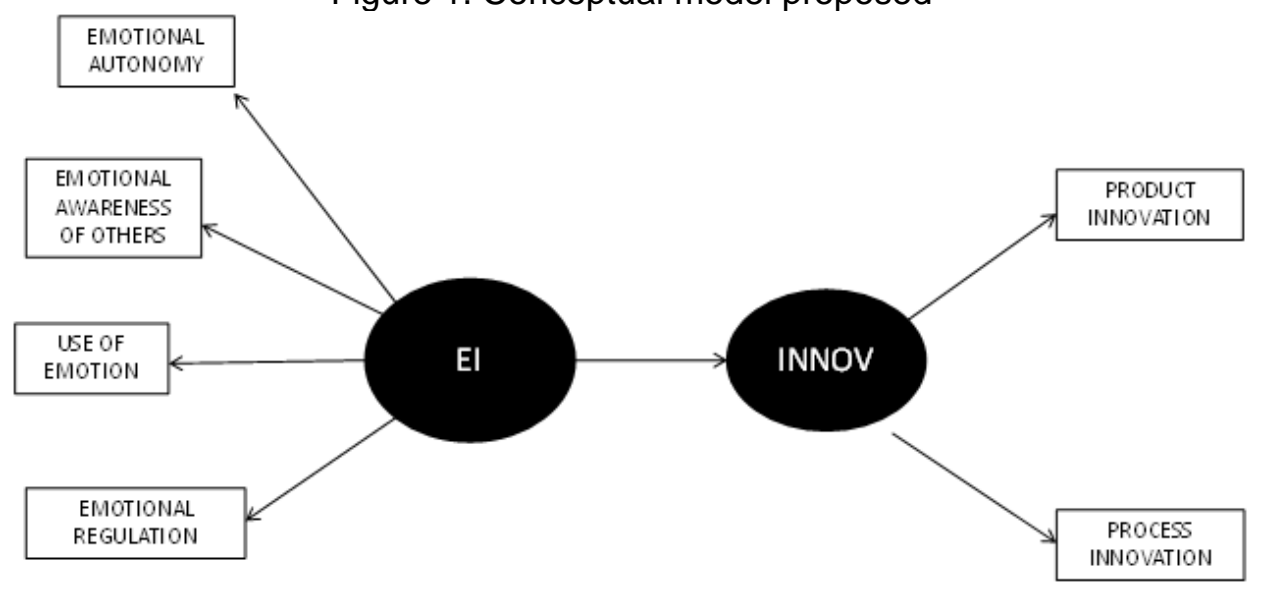

Source: compiled by authors

\section{Literature review}

\section{Emotional intelligence}

Nowadays, there is evidence that emotional intelligence is a very important predictor for the clear development of human social and personal behavior (Extremera \& Fernández Berrocal, 2005a; Schutte et al., 2001) and also has a substantial power as a transmitter of the behaviors developed around the work place across, different departments (Jordan \& Troth, 2002).

Emotional intelligence has been found to relate in a positive and important way to a enhancing the behavior one adopts, such as: more adaptable response strategies (Fernández-Berrocal, Alcaide, Extremera\& Pizarro, 2006), and a greater capacity to break off negative emotional states and sustain positive ones (Salovey, Stroud, Woolery \& Epel, 2002; Williams, Fernández - Berrocal, Extremera, Ramos \& Joiner, 2004).

Park (2005) analyzes the connection inside an organization between the emotional environment and its outcomes. Based on the hypothesis: "How far people experience an organization as enabling them to feel capable, listened to, accepted, safe and included affect their creativity and innovation" Suliman \& Al-Shaikh (2007), he finds a correlation between degree to which staff experience these five dimensions and the degree to which they observers, resilient, creative, and interdependent, besides some other qualities associated with "learning power". Park concludes that different organizations increase their likelihood of improving productiveness and creativeness by focusing upon the 
quality of the emotional background at work, and must establish aims in order to achieve these results.

On the other hand, Brooks and Nafukho (2006) attempt to show the integration between $\mathrm{El}$, human resources, social capital and organizational productivity, coming to the conclusion that El at work is clearly related to other factors. Thus, to increase their productiveness that of their different departments, organizations look to employ and develop workers with a higher El.

\section{Innovation}

Nonaka and Takeuchi (1995) regard innovation as a knowledge-creation process, whose main input is the availability of known knowledge, which needs to be capitalized and transferred to those workers taking part in the process. Nevertheless the mere fact of processing knowledge in itself does not guarantee any strategic advantage (Zack, 2002).

This present study, argues that innovate is to create or acquire an idea or knowledge and introduce it into the organization, making it possible to turn it into a new product (that is, an object) - or a new process or method.

In several senses, innovation can be described as the implementation of different discoveries and interventions and the process through which new results emerge, they be products, systems or processes (Gloet \& Terziovski, 2004).

Innovation can be understood as a broad term that defines the capacity of an enterprise to introduce new products or processes (López-Cabrales, - Pérez-Luño, \& Cabrera, 2009). In turn, Wang, et al., (2010) argue that innovation is conceptually a process that starts with a new idea and ends with its introduction into the market.

Innovation, as alluded to, can be broken down into two different areas: products and processes (Gobeli \& Brown, 1994; Yamin, Mavondo, Gunasekaran, Sarros, 1997). Product innovation refers to the process of generating new ideas or the creation of something totally new, which is reflected in the changes in the product or in the final result offered by the organization; meanwhile, process innovation represents changes in the way in which enterprises obtain final products or services, through the transmission or adoption of new innovation developed elsewhere (Tidd et al., 1997).

\section{Effects of emotional intelligence on innovation}

In 1990, Mayer and Salovey, defined El as " the ability to regulate proper feelings and emotions and the belonging to other ones, discriminate between them and use this piece of information to lead the thinking and action of a person". Mayer and Salovey (2007) through their model based on four branches, argue that El consists on four abilities: 1) perception, valuation and expression of the emotion; 2) emotional use of thinking; 3) understanding and analysis of emotions using emotional knowledge; and 4) reflexive regulation of emotions to promote emotional and intellectual development. This definition of El is widely accepted given its representativeness across all literature on El (Wong \& Law, 2002; Law et al., 2004; Shih \& Susanto, 2010). 
In the same way, the El has become crucial to achieving effective outcomes and staying at the top at times of organizational change (Diggins, 2004); the best executives should possess El so that their conclusions are based on a combination of self-management, relationship skills and self-awareness about how their behavior can affect other elements within an organization.

Although many studies have found that El has a positive effect on aptitudes and independent behaviors, labor development, and performance of team (Wong \& Law, 2002; Jordan \& Troth, 2002; Shih \& Susanto, 2010), little is known about the mechanisms in-volved between El and product and process innovation, or between El and innovation in worker outcomes.

However, Suliman and Al-Shaikh (2007), observe that workers with higher levels of El tend to report lower levels of conflict and a greater disposition to create and innovate. Employees with higher El have more power over their negotiating and problem-solving skills (Goleman, 1998), which represents the basis for creative ideas (Scott \& Bruce, 1994) and therefore, the basis of the individual innovation process.

Moreover, employees with a higher level of El have a better understanding of others' emotions, better control over their own emotions, and rarely express negative emotions at work (Davies et al., 1998).

In response to a conflict between different roles at the same workplace, emotionally intelligent individuals have the ability to lead and control their thinking and actions towards better resolution in the face of environmental demands and pressures (Van Rooy \& Viswescaran, 2004), handing the conflict in a more constructive way and achieving better results (Schlaerth et al., 2013).

Along the same lines, appropriate and efficient behavior during the management of conflicts can improve the income from individual innovation (Chen et al., 2012). In addition, employees with high El tend to share their ideas with their workmates, invite suggestions and help from their them and know how maintain lasting cooperative relations with their workmates, whereby all of them have to be creative and innovative (Su-liman \& Al-Shaikh, 2007).

On the basis of abovementioned literature, we proceed to formulate the following hypothesis:

1) The emotional intelligence of senior executives exerts a positive and direct effect upon product innovation at enterprises.

2) The emotional intelligence of senior executives exerts a positive and direct effect upon process innovation at enterprises.

\section{Methodology of analysis}

The method used to gather information is a questionnaire, which was tested on ten senior executives and five expert researches, and then adapted to the real situation of Spanish enterprises (See Table 1). 
Table 1. Questionnaire

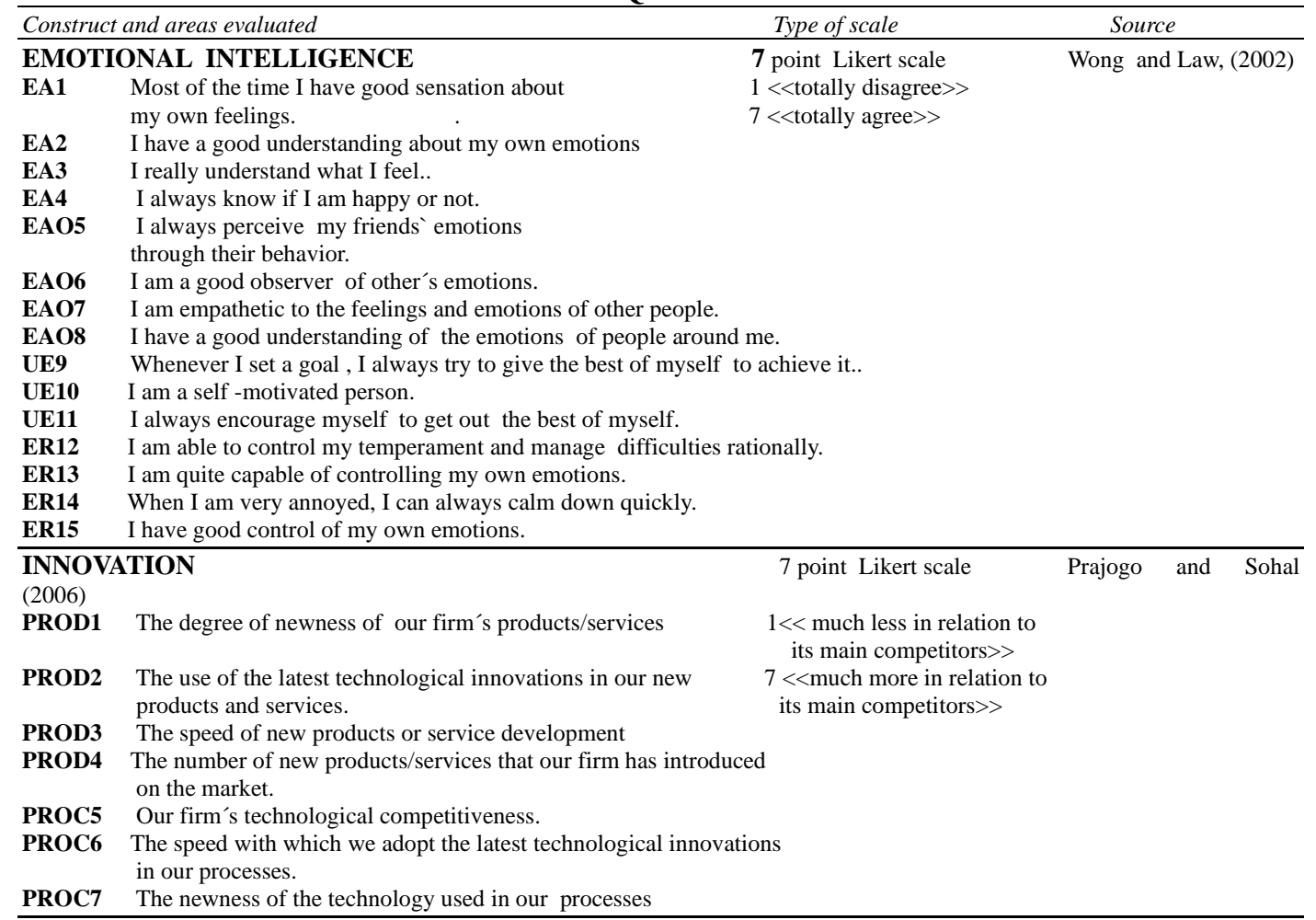

Source: compiled by authors

A random test was applied to a long list of senior executives, identified via Linkedln, belonging to enterprises engaging in a range of activities. They were sent the questionnaire by e-mail, along with a letter of introduction about the study and a link providing direct access to the survey.

The questionnaire included a total of 22 items, and each respondent was required to express their level of agreement or disagreement through a 7 point Likert scale based on the proposal of (Thwaites, 1999; Byrne, 2012 and Bentler \& Chou, 1987), with the following categories of answers: $1<<$ totally disagree $>>, 5<<$ neutral $>>, \quad 7<<$ totally agree $>>$. In turn, these are used to measure four constructors:

- Emotional intelligence by Wong and Law (2002), based on 15 items which make up four dimensions: emotional autonomy (EA); emotional awareness of others (EAO); use of emotions (UE) and emotional regulation (ER).

- Innovation outcome, based on seven items, which define two dimensions: a) product innovation (IPROD); b) Process innovation (IPROC). The scale used for measuring the results of innovation in this study was developed by Prajogo and Sohal (2006), taking into account four categories: 1) level of originality; 2) use of the latest technological developments; 3) number of innovations; and 4) speed of innovation. These classifications have been used in empirical studies previous to the innovation (Deshpande et al., 1993; Hollenstein, 1996; Miller \& Friesen, 1982; Subramanian \& Nilakanta, 1996). 
In order to calculate the descriptive statistics for each concept and to validate the different scales of the constructors, an exploratory factor analysis (EFA) with maximum likelihood is conducted using SPSS software. The EFA, as its name implies, is a technique that is mainly based on data, and attempts to discover their underlying structure (Bollen, 1989). To measure data reliability, Cronbach`s alpha (1955) is used within SPSS.

\section{Results}

As noted, the aim of this study is to determine whether the emotional intelligence of senior executives exerts a direct and positive influence on product and process innovation within enterprises, based on its four dimensions: a) emotional autonomy; b) emotional awareness; c) use of emotions, and d) emotional regulation.

Table 2 shows the main characteristics of the 139 senior executives who completed the online survey, and their enterprises.

Table 2. Sample characteristics $(\mathrm{N}=139)$

\begin{tabular}{|c|c|c|}
\hline & n & $\%$ \\
\hline $\begin{array}{l}\text { 1. Job category at the enterprise } \\
\text { Manager (President or Vice-president) } \\
\text { Department Manager } \\
\text { Technician }\end{array}$ & $\begin{array}{l}38 \\
81 \\
20\end{array}$ & $\begin{array}{l}27.34 \% \\
54.67 \% \\
17.99 \%\end{array}$ \\
\hline $\begin{array}{l}\text { 2. Age } \\
\text { Under } 25 \text { years old } \\
\text { From } 26 \text { to } 30 \text { years old } \\
\text { From } 31 \text { to } 35 \text { years old } \\
\text { From } 36 \text { to } 40 \text { years old } \\
\text { From } 41 \text { to } 45 \text { years old } \\
\text { From } 46 \text { to } 55 \text { years old } \\
\text { From } 56 \text { to } 65 \text { years old }\end{array}$ & $\begin{array}{r}1 \\
13 \\
16 \\
28 \\
32 \\
39 \\
10\end{array}$ & $\begin{array}{r}0.72 \% \\
9.35 \% \\
11.51 \% \\
20.14 \% \\
23.02 \% \\
28.06 \% \\
7.19 \%\end{array}$ \\
\hline $\begin{array}{l}\text { 3. Gender } \\
\text { Female } \\
\text { Male } \\
\end{array}$ & $\begin{array}{l}47 \\
92 \\
\end{array}$ & $\begin{array}{l}33.81 \% \\
66.19 \% \\
\end{array}$ \\
\hline $\begin{array}{l}\text { 4. Sector to which enterprise belongs: } \\
\text { Industry } \\
\text { Financial Services/Banking } \\
\text { Gestion Services } \\
\text { Technology } \\
\text { Health Services and Social Services } \\
\text { Scientists, Techniques and Professional Activities }\end{array}$ & $\begin{array}{r}14 \\
5 \\
6 \\
11 \\
25 \\
29\end{array}$ & $\begin{array}{r}10.07 \% \\
3.60 \% \\
4.32 \% \\
7.91 \% \\
17.99 \% \\
20.86 \% \\
\end{array}$ \\
\hline $\begin{array}{l}\text { Energy } \\
\text { Construction } \\
\text { Public Sector } \\
\text { Tourism and Hotel } \\
\text { Publicity and Mass Media } \\
\text { Other sectors } \\
\end{array}$ & $\begin{array}{r}4 \\
4 \\
22 \\
5 \\
4 \\
10 \\
\end{array}$ & $\begin{array}{r}2.88 \% \\
2.88 \% \\
15.83 \% \\
3.60 \% \\
2.88 \% \\
7.18 \%\end{array}$ \\
\hline $\begin{array}{l}\text { 5. Type of Enterprise } \\
\text { Public } \\
\text { Private } \\
\text { Others }\end{array}$ & $\begin{array}{r}45 \\
87 \\
7\end{array}$ & $\begin{array}{r}32.37 \% \\
62.59 \% \\
5.04 \% \\
\end{array}$ \\
\hline $\begin{array}{l}\text { 6. Autonomous Community in which the enter } \\
\text { Andalucía } \\
\text { Aragón } \\
\text { Principado de Asturias } \\
\text { Islas Baleares } \\
\text { Canarias } \\
\text { Cantabria } \\
\text { Castilla - La Mancha } \\
\text { Castilla y León } \\
\text { Cataluña } \\
\text { Comunidad Valenciana } \\
\text { Extremadura } \\
\text { Galicia } \\
\text { La Rioja } \\
\text { Comunidad de Madrid }\end{array}$ & $\begin{array}{c}\text { locate } \\
37 \\
6 \\
3 \\
4 \\
5 \\
5 \\
3 \\
9 \\
11 \\
11 \\
4 \\
6 \\
3 \\
13\end{array}$ & $\begin{array}{r}26.61 \% \\
4.32 \% \\
2.16 \% \\
2.88 \% \\
3.60 \% \\
3.60 \% \\
2.16 \% \\
6.47 \% \\
7.91 \% \\
7.91 \% \\
2.88 \% \\
4.32 \% \\
2.16 \% \\
9.35 \%\end{array}$ \\
\hline
\end{tabular}


For the estimation and representation of the model, the statistical package AMOS version 24 is used. The focus for this estimation is based upon for parameters related to the structures of Covariance or SEM (Structural Equation Models). Figure 2 shows the outcomes of the proposed Structural Equation Model.

Figure 2. SEM

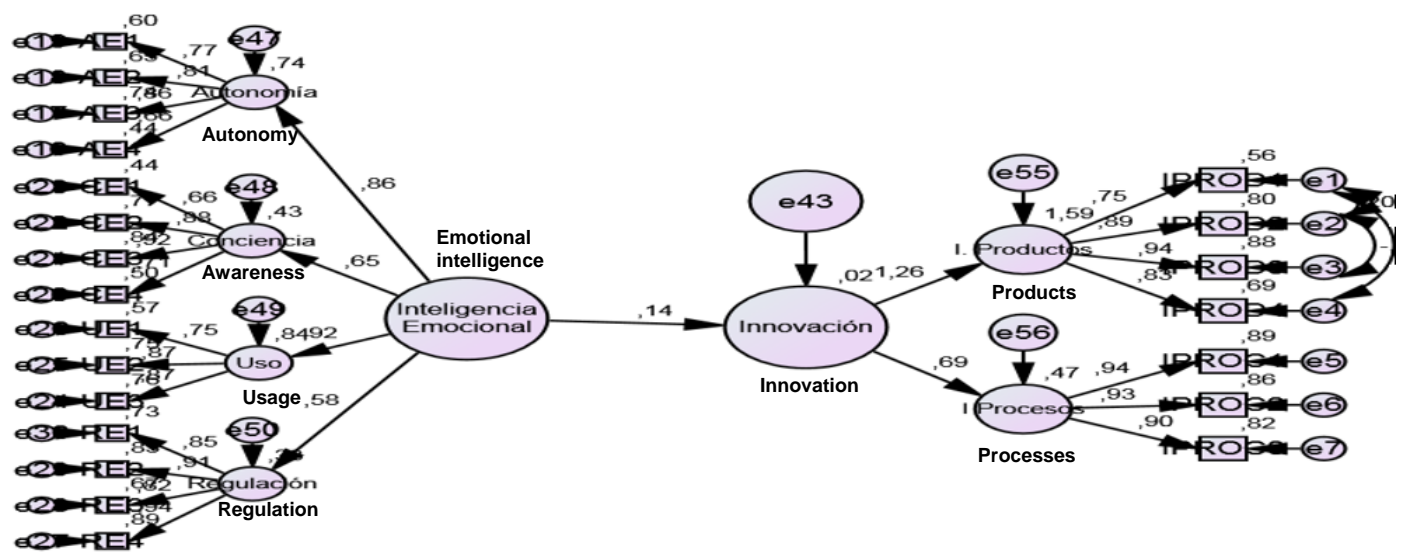

Source: Source: compiled by authors

According to the results obtained, "the starting hypothesis (see Figure 2) is fulfilled, since emotional intelligence (EI) exerts a positive and direct effect upon innovation (INNOV), exerting a much greater influence on the "product innovation" than on the "process innovation".

With respect to product innovation, El exerts a direct and positive influence in the following order of intensity: a) speed of development of new products; b) use of the latest technological innovations in products and services; c) number of products and services that the enterprise has introduced into the market; and d) degree of novelty of the enterprise`s new products and services.

In relation to the process innovation, El exerts a the direct and positive influence in the following order of intensity: a) technological competitiveness of the enterprise; b) speed with which the latest technological innovations are adopted by the enterprise; and c) newness of the technology used in the processes. After estimating the model, goodness of fit statistics were used to evaluate its quality (Schreider et al, 2006). 
Table 3. Goodness of fit statistics

\begin{tabular}{|c|c|c|}
\hline Statistic & Abbreviation & Estimated model \\
\hline \multicolumn{3}{|l|}{ Absolute fit } \\
\hline Chi-squared & $\chi^{2}$ & 429,650 \\
\hline Chi - squared/degrees of freedom & $\chi 2 / \mathrm{df}$ & 2.15 \\
\hline \multicolumn{3}{|l|}{ Incremental fit } \\
\hline Normed Fit Index & NFI & .848 \\
\hline Tucker-Lewis Index & TLI & .886 \\
\hline \multicolumn{3}{|l|}{ Parsimony fit } \\
\hline Parsimony normed fit index & PNFI & .667 \\
\hline Information Criterion & AIC & 581,650 \\
\hline \multicolumn{3}{|l|}{ Other } \\
\hline Root mean square error of approximation & RMSEA & .089 \\
\hline
\end{tabular}

The abovementioned measures are within ranges considered acceptable by the Social Sciences.

\section{Discussion}

As regards the emotional intelligence of senior executives, it is important to point out that it exerts a positive and direct influence upon innovation within the enterprise (0.14), which is consistent with the findings of Fenwick (2003) and Park (2005). It is also notable that emotional autonomy of senior executives, and these managers ' use of their emotions, have considerable weight in El. However, emotional awareness of others and emotional regulation have a lower weight.

That senior executives have emotional autonomy and make use of their emotions implies that they are truly capable of understanding - "what they feel", they have a firm grasp of their own emotions, and they are sufficiently self- motivated to get the best out of themselves. These results support the work of Davies et al., (1998).

Senior executives' emotional awareness of others also has a high weight in El, whereby it is of particular importance that these managers will be "good observers" of others" emotions, besides that he is capable of perceiving his friends emotions through their behaviours. In turn, the emotional regulation of senior executives has a lower weight, but this does not mean that it is any less important, as managers 'ability to control their own emotions and to calm down quickly when they become annoyed also has some influence upon innovation. This supports the arguments by Van Rooy and Viswescaran, (2004); Chen et al., (2012); and Suliman and Al-Shaikh, (2007), who argue that "employees with higher standards of El tend to report lower levels of conflict and higher standards of learning to create and innovate."

Therefore, the results of this study support the proposal of Mayer and Salovey (2007), for whom "emotional intelligence is the ability to unify emotions and reasoning, using our emotions to make it easier to reason and think about our emotional life a more intelligent way". The four dimensions of emotional intelligence: "Perceive, and Express, 
Understand, Make easier and Evaluate Emotions" affect decision making and support emotional and intellectual expansion (Charbonneau and Nicol, 2002).

\section{Possible limitations}

The first limitation of this present study is the small number of empirical studies in the management field that analyze the construct of El and its affects upon innovation within different enterprises. Most studies on El are related to the field of education.

But the main limitation of this study is the size of the sample and its heterogeneity.

\section{Conclusion and future lines of research}

Companies should understand that the emotional intelligence is an ability that necessarily has to be trained and developed among senior executives in order to reduce the number of problems, increase creativity, improve product and process innovation, and consequently, obtain better results.

Future lines of research could increase the number of enterprises selected and target their surveys only to the senior executives directly involved in product and process innovation in order to obtain a much more homogeneous sample.

\section{References}

Bentler, P., \& Chou, C. (1987). "Practical Issues in Structural Modeling". Sociological Methods \& Research, 16 (1), pp. 78-117.

Brooks, K., \& Nafukho, F. (2006). "Human resource development, social capital, emotional intelligence: any link to productivity?", Journal of European Industrial Training, Vol. 30 No. 2, pp. 117-28.

Byrne, B. M. (2012). Structural equation modeling with Mplus: Basic concepts, applications, and programming. New York, NY: Taylor and Francis Group.

Charbonneau, D., \& Nicol, A. (2002). Emotional intelligence and leadership in adolescents. Personality and Individual Differences, 33, 1101-1113.

Chen, X., Zhao, K., Liu, X. \& Wu, D. (2012). "Improving employees' job satisfaction and innovation performance using conflict management", International Journal of Conflict Management, Vol. 23 No. 2, pp. 151-172.

Cronbach, L. \& Meehl, P. (1955). Construct validity in psychological test. Psychological Bulletin,52, 218-302.

Davies, M., Stankov, L. \& Roberts, R. (1998). "Emotional intelligence: in search of an elusive construct", Journal of Personality and Social Psychology, Vol. 75 No. 4, p. 989.

Deshpande, R., Farley, J., \& Webster, F. (1993). Corporate culture, customer orientation, and innovativeness in Japanese firms: aquadrad analysis. J. Mark. 57, 23---27.

Diggins, C. (2004). "Emotional intelligence: the key to effective performance and to staying ahead of the pack at times of organizational change", Human Resource Management International Digest, Vol. 12 No. 1, pp. 33-5. 
Extremera, N. \& Fernández-Berrocal, P. (2005a). Inteligencia emocional y diferencias individuales en el meta-conocimiento de los estados emocionales: una revisión de los estudios con el Trait Meta-Mood Scale. Ansiedad y Estrés, 11, 101-122.

Fenwick, T. (2003). "Innovation: examining workplace learning in new enterprises", Journal of Workplace Learning, Vol. 15 No. 3, pp. 123-132.

Fernández-Berrocal, P. \& Extremera, N. (2006). Emotional intelligence: A theoretical and empirical overview of its first 15 years of history. Psicothema, 18, 7-12.

Fleury, M. \& Fleury, A. (2001). Construindo o conceito de competência. Revista de Administração Contemporânea 5 (spe), 183-196.

Forgas, J. (1995). "Mood and judgment: the affect infusion model (AIM)", Psychological Bulletin, Vol. 117 No. 1, pp. 39-66.

Gloet, M., \& Terziovski, M. (2004). "Exploring the relationship between knowledge management practices and innovation performance", Journal of Manufacturing Tecnology Management, Vol. 15 No. 5, pp. 402-9.

Gobeli, D. \& Brown W. (1994). Technological innovation strategies. Engineering Managment Journal 1994;6(1):17-24.

Goleman, D. (1998). Working with Emotional Intelligence, Random House Digital, New York, NY.

Hair, J., Anderson, Rolph E., Tatham, Ronald L., \& Black, W. (1999). Análisis Mulivariante,(5th a ed.). Madrid: Prentice Hall Iberia.

Helfat, C., \& Martin, J. (2012). Dynamic managerial capabilities: A perspective on the relationship between managers, creativity and innovation in organizations. In C. Shalley, M. Hitt, \& J. Zhou (Eds.), The Oxford handbook of creativity, innovation, and entrepreneurship: Multilevel linkages. N New York: Oxford University Press.

Hollenstein, H., (1996). A composite indicator of a firm's innovativeness. An empirical analysis based on survey data for Swiss manufacturing. Res. Policy 25, 633---645.

Jordan, P. \& Troth, A. (2002). "Emotional intelligence and conflict resolution: implications for human resource development", Advances in Developing Human Resources, Vol. 4 No. 1, pp. 62-79.

Kahneman, D. (2012). "Pensar rápido, pensar despacio". Barcelona: Debate.

Law, K., Wong, C. \& Song, L. (2004). "The construct and criterion validity of emotional intelligence and its potential utility for management studies", Journal of Applied Psychology, Vol. 89 No. 3, pp. 483-496.

Lopez-Cabrales A., Pérez-Luño, A., Valle Cabrera, R. (2009). Knowledge As A Mediator Between HRM Practices And Innovative Activity, Human Resource Man-agement, July August, Vol. 48(4).

Lyons, J. \& Schneider, T. (2005). "The influence of emotional intelligence on performance", Personality and Individual Differences, Vol. 39 No. 4, pp. 693-703.

Mayer, J. \& Salovey, P. (2007). ¿Qué es la inteligencia emocional? In, Mestre Navas, J. M. and Fernández Berrocal, P. Manual de inteligencia emocional (pp. 25-45). Madrid: Pirámide.

Miller, D. \& Friesen, P. (1982). Innovation in conservative and entrepreneurial firms: two models of strategic momentum. Strategic Management Journal 3(1):1-25. 
Nonaka, I., \& Takeuchi, H. (1995). The knowledge-creating company. How Japanese companies create the dynamics of innovations. New York: Oxford University Press.

Norman, D. \& Shallice, T. (1986). Attention to action: Willed and automatic control of behavior. In R. J. Davidson, G. E. Schwartz, \& D. Shapiro (Eds.), Consciousness and self-regulation, 1-18. New York: Plenum Press.

Park, J. (2005). "Fostering creativity and productivity through emotional literacy: the organizational context", Development and Learning in Organizations, Vol. 19 No. 4, pp. 5-7.

Prajogo, D. \& Sohal, A. (2006). The integration of TQM and technology and R\&D management in determining organizational performance --- an Australian perspective. Omega 34, 296---312.

Salovey, P., Stroud, L., Woolery, A., \& Epel, E. (2002). Perceived emotional intelligence, stress reactivity, and symptom reports: Further explorations using the Trait Meta-Mood Scale. Psychology and Health, 17, 611-627.

Schlaerth, A., Ensari, N. \& Christian, J. (2013). "A meta-analytical review of the relationship between emotional intelligence and leaders' constructive conflict management", Group Processes \& Intergroup Relations, Vol. 16 No. 1, pp. 126-136.

Schutte, N., Malouff, J., Bobik, C., Coston, T., Greeson, C., Jedlicka, C., Wendorf, G. (2001). Emotional intelligence and interpersonal relations. Journal of Social Psychology, 2001, 141, 523-536.

Scott, S., \& Bruce, R. (1994). "Determinants of innovative behavior: a path model of individual innovation in the workplace", Academy of Management Journal, Vol. 37 No. 3, pp. 580-607.

Schreider, J., Stage, F., King, J., Nora, A., Barlow, E. (2006). Reporting structural equation modeling and confirmatory factor analysis results: a review. The Journal of Education Research, 99 (6), 323-337.

Shih, H., \& Susanto, E. (2010). "Conflict management styles, emotional intelligence, and job performance in public organizations", International Journal of Conflict Management, Vol. 21 No. 2, pp. 147-168

Subramanian A. \& Nilakanta S. (1996). Organizational innovativeness: exploring the relationship between organizational determinants of innovation, types of innovations, and measures of organizational performance. Omega; 24(6):631-47.

Suliman, A. \& Al-Shaikh, F. (2007). "Emotional intelligence at work: links to conflict and innovation", Employee Relations, Vol. 29 No. 2, pp. 208-220.

Thwaites, D. (1999). Closing the gaps: service quality in sport tourism. Journal of Services Marketing, 13 (6), 500-516.

Tidd J., Bessant J., \& Pavitt K., (1997). Managing innovation: integrating technological, market, and organizational change. Chichester, UK: Wiley.

Van Rooy, D., \& Viswesvaran, C. (2004). "Emotional intelligence: a meta-analytic investigation of predictive validity and nomological net", Journal of Vocational Behaviour, Vol. 65, pp. 71-95.

Wang S., Guidice R., Tansky J., \& Wang, Z. (2010). When R\&D spending is not enough: The critical role of culture when you really want to innovate, Human Resource Management, 49(4). 
Williams, F., Fernández-Berrocal, P., Extremera, N., Ramos, N., \& Joiner, T. (2004). Mood regulation skill and the symptoms of endogenous and hopelessness depression. Journal of Psychopathology and Behavioral Assessment, 26,233-240.

Wong, C., \& Law, K. (2002). The effects of leader and follower emotional intelligence on performance and attitude: An exploratory study. The Leadership Quarterly, 13, 243-274.

Yamin, S., Mavondo, F., Gunasekaran, A. \& Sarros J. (1997). Study of competitive strategy, organizational innovation and organizational performance among Australian manufacturing companies. International Journal of Production Economics 52(1,2):16172.

Zack, M. (2002). Developing a knowledge strategy: Epilogue. In N. Bontis, \& C.W. Choo (Eds.), The strategic management of intellectual capital and organizational knowledge: A collection of readings. Oxford University Press. 